УДК 349.6

DOI https://doi.org/10.32838/TNU-2707-0581/2021.2/06

\title{
Краснова М.В.
}

Київський національний університет імені Тараса Шевченка

Краснова Ю.А.

Національний університет біоресурсів і природокористування України

\section{ПРАВОВІ ЗАСАДИ ЗАБЕЗПЕЧЕННЯ ЕКОЛОГІЧНОЇ БЕЗПЕКИ БУДІВЕЛЬНИХ МАТЕРІАЛІВ В УКРАЇНІ}

У статті представлені результати правового аналізу формування вимог із забезпечення екологічної безпеки будівельних матеріалів як одного із засобів забезпечення сталого розвитку. У роботі встановлюється, що всі будівельні матеріали поділяються на гармонійні (безпечні для довкілля та людини) і негармонійні (шкідливі для довкілля та людини), однак незалежно від иьвого діяльність із їх видобування, переробки, обробки або виготовлення визнається Законом України «Про оцінку впливу на довкілля» екологічно шкідливою. Таке вимагає запровадження спеціальних еколого-правових вимог на всіх етапах їх видобування, виготовлення та експлуатації. Тому в роботі такі правові вимоги аналізуються иляхом їх поділу на два етапи - на етап виробництвва будівельних матеріалів та на етап їх використання у будівниитві.

3'ясовано, ще етап виробництва будівельних матеріалів включає в себе три складові частини: видобування природних ресурсів, які є готовими будівельними матеріалами або виступають основною сировиною для виготовлення будівельного матеріалу; закупівля та переробка природних ресурсів, які виступають будівельними матеріалами; закупівля та переробка хімічних речовин, що лежать в основі виготовлення полімерних і полімеровмісних матеріалів. У зв'язку з тим, що більшість видів діяльності, пов'язаних із виробництвом будівельних матеріалів, визнано екологічно шкідливими, до них встановлюються вимоги щодо ідентифікаиії об'єктів на потенційно небезпечні, або об 'єкти підвищеної небезпеки, з виконанням усіх подальших вимог, що встановлюються до таких видів об'єктів. Крім того, законодавством встановлюються екологічні вимоги і до самих будівельних матеріалів, які переважно містяться в технічних документах (стандартах). У роботі встановлено, щчо законодавча вимога щодо екологічної безпечності будівельних матеріалів буде введена в Украӥні лише y 2023 poui.

Що стосується встановлення екологічних вимог на етапі використання будівельних матеріалів, то з'ясовано, що така продукиія має обов'язково проходити прочедуру підтвердження відповідності, сертифікаиії та маркування і лише після иього потрапляти на ринки для подальшого продажу і використання.

У статті піднімається питання про необхідність систематизації законодавства про забезпечення екологічної безпеки будівельних матеріалів.

Ключові слова: будівельний матеріал, якість і безпечність, екологічна безпека, життя і здоров'я людини, санітарні і гігієнічні вимоги, технічні стандарти і регламенти, систематизачія екологічних вимог до якості будівельних матеріалів.

Постановка проблеми. Сучасний стан розвитку екологічних правовідносин поглиблює та розширює правові зв'язки суб'єктів, діяльність яких характеризується підвищеним екологічним ризиком. Серед галузей господарювання, яким притаманна наявність такого ризику, визнано промисловість, в тому числі будівельних матеріалів. Галузь промисловості будівельних матеріалів є однією 3 важливих, залежних від рівня якості природних ресурсів, які можуть використовуватись для виготовлення такої продукції, що, відповідно, може впливати на життя і здоров'я людей та навколишнє природне середовище, що випливає 3 положень розділу XI Закону України «Про охорону навколишнього природного середовища» [1]. Таке підтверджується й закріпленням у ст. 3 Закону України «Про оцінку впливу на довкілля» [2] значного переліку видів діяльності та об'єктів, пов'язаних зі сферою виробництва будівельних матеріалів, які можуть мати значний вплив на довкілля. 
Принагідно згадати, що 25 вересня 2015 року резолюцією Генеральної Асамблеї ООН «Трансформація нашого світу: порядок денний у сфері сталого розвитку на період до 2030 року» [3] були закріплені цілі (індикатори) сталого розвитку на період до 2030 року, серед яких вагоме місце відводиться цілі 11 , а саме - забезпечення відкритості, безпечності, життєстійкості та екологічної стійкості міст і населених пунктів. Така ціль має бути реалізована в тому числі шляхом забезпечення населення доступним екологічно безпечним житлом.

Україною, як суб'єктом міжнародних відносин та стороною міжнародних угод зі сталого розвитку, також розробляються стратегічні документи в цьому напряму. Зокрема, 30.09.2019 р. Указом Президента України № 722/2019 були запроваджені Цілі сталого розвитку України на період до 2030 року [4], в яких визначена така ціль, як забезпечення відкритості, безпеки, життєстійкості й екологічної стійкості міст, інших населених пунктів.

На подолання негативних наслідків такої діяльності спрямована і національна екологічна політика, серед основних цілей та завдань якої $€$ : досягнення, в тому числі правовими засобами, безпечного для здоров'я людини стану довкілля; забезпечення екологічної безпеки; усунення збільшення навантаження на навколишнє природне середовище, зумовленого економічним зростанням, екологізацією всіх сфер господарювання, в тому числі екологізацією промисловості будівельних матеріалів, що передбачає, зокрема, стимулювання впровадження систем екологічного управління на підприємствах одночасно 3 поліпшенням екологічних характеристик продукції, у тому числі на основі міжнародних систем сертифікації та маркування; запровадження в Україні системи зелених закупівель (Стратегія державної екологічної політики України на період до 2030 року, затверджена Законом України від 28.02.2019 p.) [5].

Постановка завдання. Актуальність обраної теми цієї роботи зумовлена дослідженням можливих шляхів правового забезпечення екологічної безпеки будівельних матеріалів, а також тим, що такі питання ще не були об'єктом спеціального вивчення українськими правознавцями.

Виклад основного матеріалу дослідження. Будівельна промисловість вважається одним із найдавніших напрямів матеріального виробництва на Землі. У сучасному розумінні вона включає в себе комплекс сфер господарювання у складі важкої промисловості, які забезпечують суспільство найважливішими будівельними матеріалами для всіх видів будівельних робіт. Такі види робіт можна класифікувати на загальнобудівельні (арматурні, бетонні, земляні, кам'яні, покрівельні, оздоблювальні, теслярські, свайні, монтажні та інші) та на спеціальні (гідроізоляційні, теплоізоляційні, санітарно-технічні, електромонтажні та інші). В основі такої діяльності можуть бути як добування сировини для будівельних матеріалів (піску, глини, гравію, води тощо), так і їх виготовлення для будівництва як промислових, так і житлових об'єктів.

За енциклопедичним визначенням [6] будівельні матеріали і вироби можуть бути природними (камінь, дерево, глина, пісок тощо) або штучними (цемент, пластмаси, бітуми тощо). За хімічним складом - це неорганічні (мінеральні) та органічні матеріали.

Види будівельних матеріалів і технологія їх виготовлення залежні від ступеня розвитку продуктивних сил та виробничих відносин у суспільстві. Наприклад, у стародавні часи використовували найпростіші матеріали: глину, очерет, деревину, природний камінь, невипалену цеглу, випалену глиняну черепицю i т. ін., водночас з розвитком індустріалізації розпочалося виготовлення будівельних матеріалів 3 додаванням різних хімічних елементів. Нині поширення набувають вироби з бетонів на спеціальних зв'язувачах, конструкторські деталі з нових видів скла і пластмас, високоміцної та легованої сталі, легких сплавів та інших матеріалів.

У зв'язку із цим сучасна класифікація будівельних матеріалів включає такі основні групи: 1) природні кам'яні матеріали та вироби; 2) штучні кам'яні матеріали і вироби; 3) керамічні матеріали і вироби; 4) неорганічні в'яжучі речовини; 5) лужні цементи; 6) теплоізоляційні матеріали; 7) бітумні та дьогтьові в'яжучі речовини й матеріали; 8) матеріали та вироби зі скла; 9) металеві вироби; 10) матеріали та вироби з деревини; 11) лакофарбові матеріали.

За призначенням такі будівельні матеріали поділяються на: 1) матеріали для підлоги; 2) матеріали для стін та перегородок; 3) лицювальні та оздоблювальні матеріали; 4) покрівельні матеріали; 5) мінерально-в'яжучі матеріали; 6) санітарно-технічні вироби [7].

Така різноманітність будівельних матеріалів, 3 одного боку, покращує розвиток містобудівної галузі, а з іншого - вносить нові виклики для людства. Зокрема, зі спеціальної літератури відомо, 
що в даний час якість сировини для виробництва будівельних матеріалів і для самих будівельних матеріалів визначається переважно технічними стандартами, оцінюється переважно за технологічними і технічними характеристиками. Лише невелика частина окремих гігієнічних вимог у таких характеристиках подається у вигляді показників, що практично не дозволяють оцінити міру їх небезпеки для довкілля та життя і здоров'я населення. Для комплексної екологічної оцінки будівельних матеріалів доцільно мати всю сукупність їх негативних властивостей та їх впливу на довкілля та життя і здоров'я людини, тобто мати оцінку еколого-гігієнічної безпеки на всіх стадіях їх життєвого циклу, перш за все на стадії їх виготовлення, «оскільки від вибору матеріалу залежить екологічна безпека житла» [8, с. 54].

Екологічні стандарти класифікують будівельні матеріали на два види: гармонійні і негармонійні [9]. Гармонійні вважаються екологічно чистими, такими, що не містять токсичних речовин, а також піддаються вторинній переробці. Основними 3 таких матеріалів є глина, дерево, скло і деякі метали. Виготовленню такого виду будівельних матеріалів притаманне надмірне споживання природних ресурсів (лісу, корисних копалин, води тощо), а також екологічна шкідливість деяких процесів їх обробки. Негармонійні здатні завдати значної шкоди навколишньому середовищу і здоров'ю людського організму через властиву їм токсичність (лаки, фарби, клеї, масла тощо). Однак і гармонійні будівельні матеріали здатні ставати небезпечними внаслідок зовнішньої їх обробки певними хімічними речовинами.

Тому для підвищення якості будівельних матеріалів встановлюються спеціальні екологічні та гігієнічні вимоги: 1) на етапі виробництва будівельних матеріалів; 2) на етапі їх використання у будівництві.

Етап виробництва будівельних матеріалів включає в себе три складові частини: по-перше, це видобування природних ресурсів, які $є$ готовими будівельними матеріалами (пісок, глина, гравій, каміння тощо) або виступають основною сировиною для виготовлення будівельного матеріалу (мергель, залізна руда, вапно, мінеральні речовини, глина, азбест тощо); по-друге, закупівля та переробка природних ресурсів, які виступають будівельними матеріалами (наприклад, деревина); по-трете, закупівля та переробка хімічних речовин, що лежать в основі виготовлення полімерних і полімеровмісних матеріалів (лаків, фарб, еластомерів, пероксидів та інших хімічних речовин).
Кожний із названих складових елементів етапу виробництва будівельних матеріалів ст. 3 Закону України «Про оцінку впливу на довкілля» визначається як екологічно небезпечний вид діяльності.

Зокрема, перша складова частина такого виробництва включає такі екологічно небезпечні види діяльності та об'єкти: 1) видобування піску і гравію на землях водного фонду; 2) кар'єри та видобування корисних копалин відкритим способом, ï перероблення чи збагачення на місці; 3) споруди з видобування, виробництва і перероблення азбесту, азбестовмісних продуктів; 4) виробництво та обробку металу; 5) переробку мінеральної сировини, що включає: виробництво цементу або цементного клінкеру; виробництво вапна; виробництво скла, у тому числі виготовлення скляного волокна; виплавка мінеральних речовин, у тому числі виробництво мінеральних волокон; виробництво керамічних продуктів шляхом випалювання, зокрема покрівельної черепиці, цегли, вогнестійкої цегли, керамічної плитки, кам'яної кераміки або фарфорових виробів.

Для другої складової частини етапу виробництва будівельних матеріалів характерне, зокрема, оброблення деревини (хімічне перероблення деревини, виробництво деревоволокнистих плит, деревообробне виробництво 3 використанням синтетичних смол, консервування деревини просоченням).

Третій складник - хімічне виробництво, в тому числі виробництво полімерних і полімервмісних матеріалів, лаків, фарб, еластомерів, пероксидів та інших хімічних речовин; виробництво екструдованого пінополістиролу, утеплювачів, асфальтобетону, а також самі споруди для виробництва штучних мінеральних волокон.

Зазначені види діяльності і об'єкти поділені Законом України «Про оцінку впливу на довкілля» на дві категорії впливу на довкілля, що у відповідності до Закону України «Про об’єкти підвищеної небезпеки» [10] означає їх поділ на об'єкти підвищеної та потенційної небезпеки. Правове регулювання такого поділу об'єктів і видів діяльності нами вже досліджувалось в інших роботах [11, с. 286-338], тому на цьому питанні ми не будемо акцентувати увагу в цій роботі, а розглянемо детальніше правові вимоги до етапу використання будівельних матеріалів у будівництві.

Слід відзначити, що основоположні засади формування законодавчого напрямку про забезпечення екологічної безпеки будівельних матеріалів під час їх використання було закладено Директивою 89/106/ЄЕС від 21.12.1988 р. про наближення 
законодавчих, нормативних і адміністративних положень держав-членів СС відносно будівельних матеріалів [12], відповідно до якої будівельна споруда має бути спроектована і побудована таким чином, щоб не становити небезпеку для гігієни або здоров'я мешканців або сусідів, зокрема, внаслідок будь-якої з таких дій, як: 1) виділення токсичного газу; 2) наявність у повітрі небезпечних речовин або газів; 3) випромінювання небезпечної радіації; 4) забруднення або зараження води або грунту; 5) неправильне знищення стічних вод, диму, твердих і рідних відходів; 6) наявність вологи в частинах або на внутрішній поверхні споруд (п. 3 Додатку 1 до Директиви). Із цією метою до будівельних матеріалів встановлюються вимоги їх екологічної сертифікації та маркування.

Сьогодні дія цієї Директиви втратила чинність, а регулювання іiі положень продовжились у Регламенті ЄC № 305/2011 «Конструкційні та будівельні матеріали» від 09.03.2011р. [13], який фактично повторює положення Директиви.

Україна в рамках Угоди про асоціацію з Свропейським Союзом [14] зобов'язана привести вітчизняні норми у відповідність до європейських, включаючи і сферу забезпечення екологічної безпеки будівельних матеріалів.

Ураховуючи таке, проаналізуємо особливості розвитку екологічних вимог до будівельних матеріалів в українському законодавстві.

Правові засади забезпечення екологічної безпеки будівельних матеріалів, залежно від етапу їх виготовлення чи застосування, визначені цілим рядом правових норм. Зокрема, ст. 16 Конституції України [15], якою держава гарантує своїм громадянам право на безпечне для життя і здоров'я довкілля, у вітчизняному законодавстві мають бути закріплені спеціальні норми, якими встановлюються екологічні вимоги до будівельних матеріалів.

У даному випадку слід згадати й положення Декларації про державний суверенітет України, прийнятої 16.07.1990р. [16]. Саме в ній міститься розділ «Екологічна безпека», який закріплює за собою обов'язок України дбати про генофонд, екологічну безпеку громадян нашої держави, а також припиняти і забороняти будівництво і експлуатацію тих об'єктів, які можуть становити екологічну небезпеку.

Відповідні зобов' язання встановлені й у Законі України «Про охорону навколишнього природного середовища» від 25.06.1991 р., зокрема у ст. 51, яка встановлює екологічні вимоги до розміщення, проектування, будівництва, реконструкції, введення в дію та експлуатації підприємств, споруд та інших об'єктів; ст. 52, що зобов'язує охороняти навколишнє природне середовище під час застосування токсичних хімічних речовин та інших препаратів; ст. 54, яка встановлює вимоги захисту від радіоактивного забруднення; ст. 59, що зобов' язує дотримуватись екологічних вимог під час планування, розміщення, забудови та розвитку населених пунктів. Зазначені вимоги передбачені й в Законі України «Про забезпечення санітарного та епідемічного благополуччя населення» від 24.02.1994 р. [17], зокрема, в ст. 23 - забезпечення радіаційної безпеки, в тому числі й будівельних матеріалів; ст. 25 - дотримання санітарних норм при застосуванні хімічних речовин і матеріалів тощо.

Спеціальними ж нормативно-правовими актами в містобудівній сфері $є$ закони України «Про основи містобудування» [18], «Про регулювання містобудівної діяльності» [19] та «Про будівельні норми» [20]. Однак жоден із зазначених законів не містить спеціальних екологічних вимог до будівельних матеріалів.

Натомість Закон України «Про публічні закупівлі» [21] у ст. 23 передбачає необхідність застосування заходів із захисту довкілля до предмету закупівлі, яким можуть виступати, в тому числі й будівельні матеріали. Закон вказує на те, що документація конкурсних торгів повинна містити посилання на стандарти, що визначають характеристики, вимоги, умовні позначення та термінологію, пов'язану з товарами, роботами або послугами. Згідно із цією нормою замовники можуть посилатися на стандарти, які встановлюють критерії до предмету закупівель, у тому числі щодо його характеристик (наприклад, енергоефективність, екологічність, функціональні характеристики, безпека, біологічний розлад та інші екологічні характеристики). Закон також визначає, що підтвердженням якості і безпечності будівельних матеріалів, які виступають об'єктом публічних закупівель, є маркування, протоколи випробувань та сертифікати відповідності продукції. Звідсіля випливає логічний висновок про існування цілого ряду нормативних вимог, встановлених до будівельних матеріалів.

Аналіз нормативно-правового регулювання забезпечення екологічної безпеки будівельних матеріалів дозволив встановити, що більшість таких вимог сьогодні закріплені в ряді технічних документів, зокрема: в Технічному регламенті будівельних виробів, будівель і споруд [22]; ДСТУ Б А.1.1-72-2000 «Екологічні характеристики 
будівельних матеріалів. Терміни та визначення», який встановлює терміни та визначення понять у галузі будівельних матеріалів, що стосуються екологічних питань виробництва та використання таких матеріалів [23]; в ДБН В.1.2-8-2008 «Основні вимоги до будівель і споруд, безпека життя i здоров'я людини та захист навколишнього середовища» [24]. Наприклад, п. 5.2 ДБН В.1.28-2008 зазначається, які фактори впливу підлягають регулюванню даним технічним документом, зокрема: 1) забруднення, що виділяють будівельні матеріали, грунт, люди, тварини, рослини; 2) забруднення, що надходять 3 водоймищ, систем водопостачання та 3 повітря ззовні; 3) забруднення, що виділяє устаткування для горіння, інженерні мережі, вентиляційні системи, системи кондиціонування повітря; 4) вологість повітря у приміщеннях; 5) вологість на поверхнях у приміщеннях та всередині виробів; 6) іонізуючі випромінювання; 7) шум; 8) грибкове ураження будівельних виробів; 9) зараження збудниками хвороб систем водопостачання та вентиляції.

Відповідно до п. 4.2 розділу 4 ДБН В.1.2-8-2008: будівельні об'єкти задовольняють основну вимогу щодо безпеки життя і здоров'я людини та захисту навколишнього природного середовища, якщо вони запроектовані і побудовані так, що не становлять загрози в результаті: 1) витоку токсичного газу; 2) присутності небезпечних часток чи газів у повітрі; 3) небезпечного радіаційного випромінювання; 4) забруднення чи отруєння води та грунту; 5) наявності певної кількості вологи в елементах будівельних об’єктів або на їх поверхнях всередині приміщень.

Вимоги 3 охорони довкілля містяться й в ряді спеціальних технічних документів, присвячених особливостям виготовлення різних будівельних матеріалів, як-то: ДСТУ Б В.2.7-32-95 «Пісок щільний природний для будівельних матеріалів, виробів, конструкцій і робіт» [25]; ДСТУ Б А.1.155-94 «Природні піски для виробництва будівельних матеріалів. Терміни та визначення» [26]; ДСТУ Б В.2.7-79-98 «Будівельні матеріали. Мастики гідроізоляційні бутилкаучукові та бітумнобутилкаучукові. Технічні умови» [27]; ДСТУ Б В.2.7-80:2008 «Цегла та камені силікатні. Технічні умови» [28]; ДСТУ Б А.1.1-47-94 «Хімічні добавки в бетони. Терміни та визначення» [29]; ДСТУ 6810-2004 (ЕН 233-89) «Шпалери. Технічні умови» [30] та багато інших.

Виникає логічне запитання, чи достатнє для країни правове забезпечення екологічної безпеки будівельних матеріалів на рівні технічного регламентування? Видається, що ні! 3 урахуванням цього в перехідних положеннях Закону України «Про надання будівельної продукції на ринку» від 02.09.2020р., який набере чинність з 01.01.2023 р. [31] пропонується внести зміни і доповнення до Закону України «Про будівельні норми» шляхом доповнення його статтею 7-2, яка буде присвячена основним вимогам до будівель і споруд. Відповідно до ч. 4 цієї норми, основними вимогами до будівель і споруд $є$ забезпечення, зокрема: гігієни, здоров'я та захисту довкілля, тобто будівлі і споруди повинні бути запроектовані і побудовані таким чином, щоб протягом усього життєвого циклу вони не становили загрози гігієні або здоров'ю та безпеці працівників, мешканців чи сусідів та не справляли значного впливу на якість довкілля або на клімат під час їх будівництва, експлуатації та знесення, зокрема, внаслідок будь-якого з таких чинників: а) виділення токсичного газу; б) виділення в повітря всередині або зовні приміщення небезпечних речовин, летких органічних сполук, парникових газів або небезпечних часток; в) виділення небезпечної радіації; г) виділення небезпечних речовин у грунтові води, морські води, поверхневі води або грунт; д) виділення небезпечних речовин у питну воду або інших речовин, що негативно впливають на питну воду; е) аварійного скидання стічних вод, твердих чи рідких відходів, виділення димових газів; є) сирості у частинах будівель або споруд чи на поверхнях всередині будівель або споруд, а також як окремий напрямок - можливість використання екологічно сумісних сировинних і вторинних матеріалів у будівлях і спорудах.

Отже, в державі лише формуються законодавчі вимоги до екологічної безпечності будівельних матеріалів. Вважаємо, що таке формування має включати в себе і розвиток підзаконних нормативно-правових актів, що розкриватимуть особливості забезпечення екологічної безпеки різних видів будівельних матеріалів на усіх етапах їх виготовлення і реалізації, що відповідатиме вимогам систематизації такого законодавства.

Закон України «Про публічні закупівлі» визначає, що підтвердженням якості і безпечності будівельних матеріалів, які виступають об'єктом публічних закупівель, $є$ процедури їх маркування, протоколи випробувань та сертифікати відповідності, які передбачені законами України «Про технічні регламенти та оцінку відповідності [32]», «Про стандартизацію» від 05.06.2014 р. [33] та «Про захист прав споживачів» від 12.05.1991 p. [34]. Сьогодні в будівельній галузі діє спеціальний 
технічний документ, який регулює ці питання. Ним є ДСТУ Б А.1.2-1:2007 «Система ліцензування та сертифікації у будівництві. Оцінювання відповідності у будівництві згідно з технічним регламентом будівельних виробів, будівель і споруд. Основні положення» [35].

Висновки. Таким чином, правове забезпечення екологічної безпеки будівельних матеріалів можна розглядати, в першу чергу, як сукупність правових норм, що регулюють правовідносини із виготовлення, реалізації та застосування будівельних матеріалів, екологічна безпечність яких має підтверджуватись застосуванням заходів із маркування, протоколів випробувань та сертифікатів відповідності. Відповідальність за якість будівельних матеріалів сьогодні мають нести, по-перше, суб'єкти - виробники таких матеріалів, по-друге, суб' єкти містобудівної діяльності, які на підставі публічних закупівель придбавають відповідної якості будівельний матеріал.

3'ясовано, що законодавче регулювання питання забезпечення екологічної безпеки будівельних матеріалів в Україні знаходиться на стадії свого формування та потребує систематизації, хоча тривалий час такі питання визначаються нормативно-технічною документацією.

\section{Список літератури:}

1. Про охорону навколишнього природного середовища : Закон України від 25.06.1991 p. URL: https://zakon.rada.gov.ua/laws/show/1264-12\#Text (дата звернення: 25.01.2021).

2. Про оцінку впливу на довкілля: Закон України від 01.12.2020 p. URL: https://zakon.rada.gov.ua/laws/ show/2059-19\#Tеxt (дата звернення: 20.02.2021).

3. Преобразование нашего мира : Повестка дня в области устойчивого развития на период до 2030 года: резолюция Генеральной Ассамблеи ООН от 25.09.2015 г. URL: https://undocs.org/ru/A/RES/70/1 (дата звернення: 15.02.2021).

4. Про Цілі сталого розвитку України на період до 2030 року : Указ Президента України від 30.09.2019 p. № 722/2019. URL: https://www.president.gov.ua/documents/7222019-29825 (дата звернення: 15.02.2021).

5. Про основні засади (стратегію) державної екологічної політики України на період до 2030 року : Закон Українивід28.02.2019p.URL: https://zakon.rada.gov.ua/laws/show/2697-19\#Tеxt(датазвернення: 15.03.2021).

6. Будівельні матеріали і вироби. Енциклопедія сучасної України. URL: http://esu.com.ua/search_articles. php?id=36526 (дата звернення: 25.01.2021).

7. Вимоги до якості будівельних товарів. Маркування, зберігання будівельних матеріалів та санітарнотехнічних виробів. URL: https://comexpert.pto.org.ua/?option=com_k2\&view=item\&id=1500:1500 (дата звернення: 15.03.2021).

8. Григор'єва Л., Томілін Ю., Макарова О. Проблеми екологічної оцінки будівельних матеріалів за показниками їх гігієнічної безпеки. Управління якістю в освіті та промисловості: досвід, проблеми та перспективи: тези доповідей III Міжнародної науково-практичної конференції пам'яті професора Петра Столярчука. Львів : Видавництво Львівської політехніки, 2017. С. 5455 (дата звернення: 25.01.2021).

9. Екологічна безпека будівельних матеріалів. URL: http:/www.ssa.ru/articles/entry/378582ad9 (дата звернення: 25.01.2021).

10. Про об’єкти підвищеної небезпеки : Закон України від 18.01.2002 p. URL: https://zakon.rada.gov.ua/ laws/show/2245-14\#Text (дата звернення: 03.03.2021).

11. Краснова Ю.А. Право екологічної безпеки в Україні : дис... докт. юрид. наук: 12.00.06. Національний університет біоресурсів і природокористування України. Інститут економіко-правових досліджень НАН України. Київ, 2018. 516 с.

12. Council Directive of 21 December 1988 on the approximation of law, regulations and administrative provisions of the Member States relating to construction products. OJ L 40. 11.02.1982. 12 р. (дата звернення: 14.02.2021).

13. Регламент СС 305/2011 про встановлення гармонізованих умов для розповсюдження на ринку будівельної продукції і відміни Директиви 89/106/ЄEC. URL: https://bmtrada.com.ua/wp-content/uploads/2018/05/ regulation_305_2011.pdf (дата звернення: 14.02.2021).

14. Угода про асоціацію між Україною, з однієї сторони, та Європейським Союзом, Європейським співтовариством з атомної енергії і їхніми державами-членами, з іншої сторони від 27.06.2014 p. URL: https://zakon.rada.gov.ua/laws/show/984 011\#Text (дата звернення: 14.02.2021).

15. Конституція України від 28.06.1996 p. URL: https://zakon.rada.gov.ua/laws/show/254\%D0\%BA/96$\% \mathrm{D} 0 \% \mathrm{~B} 2 \% \mathrm{D} 1 \% 80 \#$ Text. (дата звернення 25.01.2021).

16. Декларація про державний суверенітет України від 16.07.1990 p. URL: https://zakon.rada.gov.ua/laws/ show/55-12\#Text (дата звернення: 25.01.2021). 
17. Про забезпечення санітарного та епідемічного благополуччя населення : Закон України від 24.02.1994 p. URL: https://zakon.rada.gov.ua/laws/show/1264-12\#Text (дата звернення: 25.01.2021).

18. Про основи містобудування : Закон України від 16.11.1992 p. URL: https://zakon.rada.gov.ua/laws/ show/2780-12\#Text (дата звернення: 25.01.2021).

19. Про регулювання містобудівної діяльності : Закон України від 17.02.2011 p. URL: https://zakon.rada. gov.ua/laws/show/3038-17\#Text (дата звернення: 25.01.2021).

20. Про будівельні норми : Закон України від 05.11.2009 p. URL: https://zakon.rada.gov.ua/laws/ show/1704-17\#Text (дата звернення: 25.01.2021).

21. Про публічні закупівлі : Закон України від 25.12.2015 p. URL: https://zakon.rada.gov.ua/laws/ show/922-19\#Text (дата звернення: 25.01.2021).

22. Про затвердження Технічного регламенту будівельних виробів, будівель і споруд : постанова Кабінету Міністрів України від 20 грудня 2006 року № 1764. URL: https://zakon.rada.gov.ua/laws/show/1764-2006$\% \mathrm{D} 0 \% \mathrm{BF} \#$ Text (дата звернення: 24.03.2021).

23. ДСТУ Б А.1.1-72-2000 «Екологічні характеристики будівельних матеріалів. Терміни та визначення». URL: http://online.budstandart.com/ua/catalog/doc-page.html?id_doc=5061 (дата звернення: 24.03.2021).

24. ДБН В.1.2-8-2008 «Основні вимоги до будівель і споруд, безпека життя і здоров'я людини та захист навколишнього середовища». URL: https://www.minregion.gov.ua/wp-content/uploads/2017/03/DBN-V.1.2-82008.pdf (дата звернення 25.01.2021).

25. ДСТУ Б В.2.7-32-95 «Пісок щільний природний для будівельних матеріалів, виробів, конструкцій і poбiт». URL: https://bud-kiev.com.ua/wp-content/uploads/2019/02/27-32-95.pdf (дата звернення: 24.03.2021).

26. ДСТУ Б А.1.1-55-94 «Природні піски для виробництва будівельних матеріалів. Терміни та визначення». URL: http://online.budstandart.com/ua/catalog/doc-page.html?id_doc=5044 (дата звернення: 24.03.2021).

27. ДСТУ Б В.2.7-79-98 «Будівельні матеріали. Мастики гідроізоляційні бутилкаучукові та бітумнобутилкаучукові. Технічні умови». URL: http://online.budstandart.com/ua/catalog/doc-page?id_doc=4665 (дата звернення: 24.03.2021).

28. ДСТУ Б В.2.7-80:2008 «Цегла та камені силікатні. Технічні умови». URL: http://www.tbk.ks.ua/files/ pricedoc/dstu_silikat.pdf (дата звернення: 26.03.2021).

29. ДСТУ Б А.1.1-47-94 «Хімічні добавки в бетони. Терміни та визначення». URL: http://online.budstandart.com/ua/catalog/doc-page.html?id_doc=26622 (дата звернення: 26.03.2021).

30. ДСТУ 6810-2004 (ЕН 233-89) «Шпалери. Технічні умови». URL: http://online.budstandart.com/ru/ catalog/doc-page?id_doc=70420 (дата звернення 25.01.2021).

31. Про надання будівельної продукції на ринку : Закон України від 02.09 .2020 p. URL: https://zakon.rada.gov.ua/laws/show/850-20\#Text (дата звернення 25.01.2021).

32. Про технічні регламенти та оцінку відповідності : Закон України від 15.01 .2015 р. URL: https://zakon.rada.gov.ua/laws/show/124-19\#Tеxt (дата звернення: 26.03.2021).

33. Про стандартизацію : Закон України від 05.06.2014 p. URL: https://zakon.rada.gov.ua/laws/ show/1315-18\#Теxt (дата звернення: 26.03.2021).

34. Про захист прав споживачів : Закон України від 12.05.1991 p. URL: https://zakon.rada.gov.ua/laws/ show/1023-12\#Теxt (дата звернення: 26.03.2021).

35. ДСТУ Б А. 1.2-1:2007 «Система ліцензування та сертифікації у будівництві. Оцінювання відповідності у будівництві згідно з технічним регламентом будівельних виробів, будівель і споруд. Основні положення». URL: http://profidom.com.ua/a-1/a-1-2/1095-dstu-b-a-1-2-12007-sistema-licenzuvanna-ta-sertifikaciji-ubudivnictvi-ocinuvanna-vidpovidnosti-u-budivnictvi-zgidno-z-tehnichnim-reglamentom-budivelnih-virobivbudivel-i-sporud-osnovni-polozhenna (дата звернення: 26.03.2021).

\section{Krasnova M.V., Krasnova Yu.A. LEGAL BASIS OF ENVIRONMENTAL SAFETY OF BUILDING MATERIALS IN UKRAINE}

The article presents the results of the legal analysis of the formation of requirements for environmental safety of building materials as one of the means of ensuring sustainable development. The paper establishes that all building materials are divided into harmonious (safe for the environment and human) and disharmonious (harmful to the environment and human), but regardless of this, the activity of their extraction, processing, treatment or manufacture is recognized by the Law of Ukraine "On environmental impact assessment" as environmentally harmful. This requires the introduction of special environmental and legal requirements at all stages of their extraction, manufacture and operation. Therefore, in the paper such legal requirements are analyzed by dividing them into two stages - at the stage of production of building materials and at the stage of their use in construction. 
It was found that the stage of production of building materials includes three components: extraction of natural resources, which are finished building materials or are the main raw material for the manufacture of building materials; purchase and processing of natural resources, which are building materials; purchase and processing of chemicals underlying the manufacture of polymeric and polymer-containing materials. Due to the fact that most types of activities related to the production of building materials are recognized as environmentally harmful, requirements are set for them to identify objects as potentially dangerous or high-risk objects with the fulfillment of all subsequent requirements established for such types of objects. In addition, the legislation sets environmental requirements for the construction materials themselves, which are mainly contained in technical documents (standards). It is established that the legislative requirement for environmental safety of building materials will be introduced in Ukraine only in 2023. As for the establishment of environmental requirements at the stage of using building materials, it was found that such products must go through the procedure of conformity confirmation, certification and labeling, and only then enter the markets for sale and use.

The article raises the question of the need to systematize the legislation on environmental safety of building materials.

Key words: building material, quality and safety, ecological safety, human life and health, sanitary and hygienic requirements, technical standards and regulations, systematization of ecological requirements to the quality of building materials. 